Modern Asian Studies 39, 4 (2005) pp. 981-1005. (C) 2005 Cambridge University Press doi:10.1017/S0026749X05001915 Printed in the United Kingdom

\title{
Mullahs, Migrants and Murids: New Developments in the Study of Pakistan A Review Article
}

\author{
MAGNUS MARSDEN
}

Centre of South Asian Studies, University of Cambridge

The Ulama in Contemporary Islam: Custodians of Change. By Munammad

Qasim Zaman. Princeton, N.J. and Oxford: Princeton University Press.

Migrants and Militants: Fun and Urban Violence in Pakistan. By

Oskar VerkaAik. Princeton, N.J.: Princeton University Press.

Pilgrims of Love: The Anthropology of a Global Sufi Cult. By PNina Werbner.

London: Hurst and Company.

\section{Introduction}

Since the September 11 th 2001 terrorist attacks on America the study of Pakistan in the social sciences has grown both in scholarly stature and global importance. New works on Pakistan are one dimension of the rash of recent publications on 'political Islam', and this growing body of literature includes both popular and more scholarly accounts of contemporary Pakistan. ${ }^{1}$ Many such works, however, have suffered as a result of both their hasty preparation and their inadequate attempts to relate their accounts of religion and politics in Pakistan to the socalled 'war on terror'. The least sophisticated of such studies represent Pakistan as a country awash with 'fundamentalist Muslims' in the process of passively and unthinkingly embracing the 'Talibanisation' of their lives (e.g. Levy 2003). The relatively more sophisticated of these recent accounts claim that Pakistan is a complex nation-state in which there is a wide variety of different ways of being Muslim

\footnotetext{
${ }^{1}$ For scholarly contributions, see Nasr 2001, Jaffrelot (ed.) 2002 (a) Jafrelot (ed.) 2002 (b). Recent journalistic accounts include Bennett Jones 2002.

0026-749X/05/\$7.50+\$0.10
} 
but that, in the context of the present day, it is the parties of socalled 'reformist Islam' that are all powerful, and the authority of their leaders is something that goes largely unchallenged. ${ }^{2}$

The central aim of this article is to explore the significance of three recent works for the study of politics and religion in contemporary Pakistan. At the same time, I seek to highlight themes in the study of Pakistan society that would benefit either from a greater attention by social scientists, or a renewed attention through theoretical comparisons which, whilst now central to the study of both other South Asian states and Muslim-majority countries, are rarely recognised as being relevant for the study of Pakistan.

One of the distinguishing features about the works explored here is the important emphasis they place on comparison with other South Asian countries and Muslim-majority states. With some notable exceptions (e.g. Jalal 1995), there is a lingering tendency for Pakistan specialists to depict 'Pakistani Islam' as unique and distinct. For instance, the Islamic tradition in Pakistan is often said to have been detached from its broader South Asian past, at the same time as having little in common with the so-called Islamic heartlands of the Middle East. Moreover, it is not only the form of Islam in Pakistan that has been treated in this way: the study of political culture in Pakistan is also largely held to be as much about the ongoing legacies of subcontinent's partition as the forms of social transformations that have occurred since 1947. Indeed, in much of the large body of literature on Pakistan, years of military rule, antagonistic relations with neighbouring countries, and a state that is both unable and unwilling to challenge the power of the country's elite classes in its political structure as well as culture, have overshadowed the forms of transformation that Pakistanis themselves have actively engaged in since independence.

The lack of a detailed approach to social, religious and political transformation in the study of Pakistan is important, and deserves further explanation. One reason for the eclipsing of the form taken by social and political change and transformation in contemporary Pakistan in much recent work on Pakistan is the lack of any in-depth study of Pakistan's political culture as opposed to its political structure. In particular, there are few detailed studies into the forms taken by

${ }^{2}$ Many of the articles on Islam in Pakistan in Jaffrelot (ed.) 2001 which emphasise the power of complex networks of Islamist political parties in Pakistan give the impression that the teachings and messages of such movements go unquestioned. 
political and religious action and mobilisation in Pakistan, despite the historical and contemporary importance that an array of movements ranging from so-called 'secular' political parties to religious and ethnic movements have played in the country's recent political fortunes. Instead, theoretically sophisticated yet largely top-down studies of the Pakistan state, and the strength of the military and other socalled elite forces and classes, continue to largely dominate scholarly understanding of Pakistan's political culture. ${ }^{3}$ Within this paradigm, both Islamist political parties and ethnic movements, especially, are simply understood as reactions to an existing political structure; they are important not for the content of their ideologies but because of the socio-economic conditions that have created them. This form of argument is unlike that in other South Asian settings, especially India, where a combination of high-level political and detailed local studies has long been a feature of both historical and anthropological work, and something that has generated new perspectives on the nature of the interaction between religion and politics. ${ }^{4}$

As a result of both the rather sensationalist and disciplinary divided nature of Pakistan studies, there have been few attempts to understand the multi-dimensional nature of Pakistan's political and religious culture. Whilst most if not all scholars are more than willing to describe Pakistan as a 'complex cultural entity', what this means exactly for the form of the country's political culture and the composition of the Pakistan state remains unclear. Indeed, when scholars do seek to elucidate on this complex issue their attentions dwell on the relationship between the growing economic and political dominance of Punjab and the impact this has had on 'centre-province' relations. ${ }^{5}$ Much of this work is sophisticated and convincing in important ways, and it no longer treats Pakistan's Punjab as an essential and homogeneous entity in the way that earlier accounts tended towards, yet its broader implications are rarely the subject of sustained comment. ${ }^{6}$ For instance, it could now be speculated

${ }^{3}$ Jalal's historical accounts Pakistan's political culture are the most sophisticated works of this kind, see, especially, Jalal 1984, 1989 and 1995. Compare Samad 1995 a.

${ }^{4}$ Few accounts of Pakistan's political culture seek to build on, for instance, anthropological work in the country, whilst anthropologists have hitherto rarely intervened in key debates about the state of Pakistan more generally. For one anthropologist's attempt to make broader conclusions about politics and society in Pakistan see Lindholm 1996.

${ }^{5}$ On the 'Punjabisation' of Pakistan, see Talbot 2001 and Samad 1995 b.

${ }^{6}$ Cloughly's work on the dominance of the Punjab in the Pakistan Army, for instance, shows how only a very limited proportion of the Punjab's administrative 
that the growing political and economic dominance of the Punjab, combined with the failure of ethno-nationalist parties and movements to maintain their influence in the non-Punjab provinces because of the high degrees of ethnic diversity even within these regions, has meant that diverse 'Islamist' parties with a broader Pakistan support base are now amongst the most politically powerful movements that seek to represent the aspirations and concerns of the North West Frontier and Baluchistan provinces at Pakistan's political centre. ${ }^{7}$

A more detailed exploration of this hypothesis could prove informative, yet in order to give this important theme in the study of Pakistan the significance it deserves scholars must also explore concerns of broader importance. In this field of the study of Pakistan there is an especially great need for more historically informed accounts exploring how forms of cultural codification and objectification initiated by the colonial state, and later adopted and transformed after 1947, have shaped the contemporary claims of cultural and religious collective entities and identities that are now a dynamic feature of Pakistan's political culture. These issues are so complex and important in Pakistan because many Islamic movements have sought to homogenise both Muslim thought and identity in the country, and often depict any form of variation within the Muslim umma in the country as a sign of weakness and lack of unity. Thus, along with more detailed explorations of the forms taken by 'cultural diversity' in Pakistan, there is also an urgent need to explore how Muslims in Pakistan, especially those who support 'Islamist' parties, conceptualise forms of identity rooted in locality and negotiate the homogenising claims made upon them by Islamizing Muslims who purport to represent abstract and religious types of collective entities. ${ }^{8}$

The relationship between the centre and the provinces, the role played by cultural and religious collective entities and identities in mediating this encounter, and the emergence of Islamist forms of

districts have benefited from a long-term relationship with Pakistan's most important state institution, see Cloughly 2000.

7 There is an informative body of literature on 'ethno-nationalist' movements and parties in Pakistan's non-Punjab provinces. For anthropological and historical studies of ethnically Pukhtun political parties and movements, see Banerjee 2000 and Shah 1999, and on Baluch 'ethno-nationalism' and identity, see Harrison 1978 and Titus (ed.) 1997 and Titus 1999.

${ }^{8}$ There is an emerging body of comparative historical literature now emerging on the relationship between locality and abstract religious identity in the study of Kashmir, see Rai 2004 and Zutshi 2004. 
identity, are all dimensions of life in contemporary Pakistan that have increased in significance since the successes of the alliance of religious parties (the MMA, or Muttahida Majlis-e Amal) in the October 2002 elections. This alliance was especially successful in the provinces of Baluchistan and the North West Frontier-regions that have long had a tense and, sometimes, violent relationship with both the Pakistan centre and, more generally, the Punjab. Yet even the success of the MMA has thus far largely been conceptualised by both scholars and popular commentators as the product of growing Islamic sentiment, especially in Pukhtun-dominated regions, in the wake of the American attacks on Afghanistan's Taliban government. ${ }^{9}$ Analysts have also emphasised the significance of the very real attempts made by Pakistan military government to weaken the role of Pakistan's 'secular' political leadership, and the implications this had for the array of political choices available to Pakistan's electorate. There is a certain level of truth in this explanation, but it also comfortably sits within an older Orientalist paradigm of understanding Muslim politics, especially in rural and relatively remote regions, as dominated by the intensity of Muslim emotional responses and the instrumental power of elites, and not by broader socio-economic processes and transformations and thoughtful political decision-making. In making these assumptions, this form of analysis of the complexity of the relationship between Islam and politics in Pakistan conceals far more than it reveals about the form of the country's political culture today.

The full significance, I would contend, of the inroads made by political parties in Pakistan with diverse types of Islamic platforms can only be fully understood if a number of dynamic dimensions of Pakistan's political culture are examined in a more nuanced manner than is usually the case. Above all else, perhaps, there is a great need for scholars of the country to challenge assumptions concerning the nature of political authority in Pakistan. ${ }^{10}$ Despite the ongoing power and influence of the military and various elite classes, unique forms of democratic process, thought and experience are an integral feature of Pakistan's political culture. The role played by critical political debate cannot be underestimated in Pakistan, be it in the pulpits of

${ }^{9}$ The paucity of current debate surrounding the success of the MMA in the October 2002 elections is especially concerning considering Nasr's excellent accounts of the history of the Pakistan Jama'at-e Islami, see Nasr 1994 and 1996.

${ }^{10}$ Recent anthropological accounts of so-called authoritarian regimes and states in the Middle East have, for instance, advanced in theoretically sophisticated ways the understanding of authoritarianism and 'the state'. 
the country's mosques, or in vernacular language university journals, yet there have been few studies that have sought to capture the nature of critical political engagement in Pakistan, and the implications this has for understanding the nature of democracy and authoritarianism in the country.

The presence of vibrant political discussion in Pakistan has meant is that older forms of political culture and the forms of power relations upon which they build have not gone uncontested in the country, and that Pakistan is certainly not defined either by an archaic culture of feudalism or by a 'state' Islamised in a one-dimensional manner. ${ }^{11}$ Yet until very recently, at least, the dominant way of conceptualising emergent forms of religious politics in Pakistan revolved around considerations of older and, indeed, important themes concerning rural-urban migration, the experience of poverty and corruption, the persistence of class and status divisions, and posited relationship between these social dynamics and growing levels of support for 'Islamist' movements (e.g. Nasr 1992). As a result, what is lacking in much of the literature is any attempt to understand the impact that so-called religious parties and movements have had not simply on the form of the relationship between Islam and state power in Pakistan, or, indeed, on the everyday religious lives of Pakistan's Muslims, but, rather, on the nature of critical debate and democratic processes in the country today. In this literature, the very nature of 'Islamism', the lived experiences of the 'jihadi', the form taken by the Pakistan 'state', and the dynamics of rural-urban migration, for instance, remained at best unproblematised and at worst considered of little interest for the understanding of Pakistan's political culture.

The books under review here, however, in different ways, challenge these assumptions and present detailed ethnographic and historical accounts of Pakistan about dimensions of life in the country that have rarely been the focus of sustained comment. Their first major contribution is that they show how despite the constraints imposed by prolonged and repetitive periods of military rule in Pakistan, new forms of political mobilisation and action have emerged in the country, sometimes with an ethnic orientation, at other times with an Islamic one, and that these have played a central role in transforming the nature of both the country's political culture and the form of the Pakistan state. They show how movements and political parties long

${ }^{11}$ See Hansen 1999 and 2001 on Hindutva politics in Mumbai. 
dismissed as being excessively violent, traditionalist, primordialist or even terrorist in their aims and organisation are, rather, the product of modern and global changes that have affected Pakistan just as they have countries with a more stable democratic history and political culture. Moreover, in their analysis of this, they argue that despite the ongoing strength of the military-bureaucratic elite in the country Pakistan's political culture can only be understood in relation to the forms of transformation that diverse forms of democracy bring to a culturally and politically diverse array of contemporary states and societies.

The second major contribution of these works is their focus on settings as well as classes of people in Pakistan that have rarely been the focus of sustained research: the ulama, the urban youth, and the rural as well as 'diaspora' disciples (muridan) of Sufi cults. Importantly, they show convincingly how Pakistan people trained as 'religious scholars', supporters of ethnic-based parties, and the disciples of saint-like figures of spiritual charisma and authority are not simple automatons instrumentally directed either by the Pakistan state or unchanging and static religious and cultural traditions and values. They are, rather, an active and creative part of the country's changing political culture. This is a critical development in the study of Pakistan and one that has broader implication for the study of Muslim politics in other settings. Despite some notable exceptions, it continues to be too often assumed by both popular commentators and scholars that there are few possibilities for the living of creative lives within Islam. Islam's 'men of learning and piety' (the ulama), for instance, continue to be conceptualised by many Islam specialists as merely involved in 'an endless round of interpretation and reinterpretation' (Lindholm 2002: 124).

These books also challenge another major assumption about the form of 'Muslim politics' in the world today. Emergent forms of Muslim politics continue to be largely categorised as belonging to either one or a combination of a number of narrow types ranging between traditionalist Sufis, modernist and Westernizing Muslims, reformist Islamists, and 'neo-fundamentalist' traditionalists (e.g. Roy 1994). Yet all of the books under review here show how Muslims in Pakistan at least have creatively deployed, engaged, and challenged historically important Islamic concepts, teachings and figures of authority in ways that offer them the possibility of confronting the contemporary problems they face in their everyday lives, and that Islam's ulama are themselves in engagement both with the world of politics and theology 
that entails the active and creative deployment of the intellect, and it is to the men of learning and piety in Pakistan's to which I now turn.

\section{The Ulama in Contemporary Islam}

Of the many works published on Islam, the state of the contemporary Muslim world, and the politics of Pakistan in the aftermath of the September 11 th terrorist attacks on the US, Qasim Zaman's The Ulama in Contemporary Islam: Custodians of Change, is one of the more original contributions to this most important field of study. Focusing on the role and influence of Islam's 'men of learning and piety' (the ulama) in British India, present day Pakistan, and other contemporary Muslim-majority states, most notably Egypt, this is an ambitious work of great relevance to historians of South Asia, scholars of the Muslim world, and those with broader theoretical interests in the interaction between religion and politics in the modern world. The book's central argument is that the ulama in Pakistan are both an influential force in the country's politics and that they also contribute in critical ways to both older and newer intellectual debates within the Islamic tradition. Arguing such, it is a timely contribution to our understanding of present day Pakistan, and provides an interesting theoretical perspective to reflect on recent development in the country's current political climate: the October 2002 general elections saw ulama-based parties securing considerable influence at both the provincial and federal levels of the country's political organisation.

In the expanding body of literature on so-called Islamism, fundamentalism and the Islamic revival in contemporary Pakistan, there has been a lack of detailed work on the role played by the ulama in the politics of the country (Nasr 2001; Jaffrelot 2001). Indeed, more broadly, many Islam specialists have turned their analytical focus away from Islam's religious authorities to the central role which they argue is being played by newly educated 'lay' Muslims in political, social and intellectual debates emerging across the Muslim world. ${ }^{12}$ Zaman, however, throws new light on the strategies employed by the ulama in their engagement with politics in contemporary Pakistan, and the ways in which they have set to the fraught task of interacting both with colonial and post colonial regimes-many of

12 See, especially, Eickelman and Anderson (ed.) 1999. 
which have been deeply suspicious of religion and the activities of Islam's 'men of learning and piety'. The author does not, however, fall into the well worn trap of neglecting the complex role of religious thought in the 'politicisation' of Islam by Pakistan's ulama: Zaman also seeks to emphasise the ongoing intellectual impact that the ulama have on styles of Islamic thought and disputation. By exploring this important issue, Zaman at once both avoids labelling Pakistan's religious authorities as 'unthinking' jihadis as well as alerting us to the need to challenge the notion that expanding levels of mass education in Muslim-majority states has inevitably resulted in the weakening of the ulama's authority as well as intellectual influence.

A central component of the argument of this complex book is that the ulama in South Asia, far from being a stagnant force unable to interact with the conditions of modernity, are, rather, capable of change and adaptation in current conditions of sociopolitical transformation. In arguing such, Zaman provides both new theoretical perspectives as well as in-depth material on the notions of 'tradition' and 'modernity', and the role they are playing in discourses about the so-called 'Islamic revival'. By analysing important textual material produced by South Asia's ulama over the past century, Zaman convincingly shows that in the face of growing levels of education and regimes hostile to their position in society, the ulama have sought to define 'religion' as a separate sphere and themselves as 'religious specialists'. Zaman argues that both of these developments are highly novel, and that by embarking on such a course of action the ulama have been successful in maintaining and indeed enhancing their influence as political and religious agents in contemporary Pakistan. Zaman recognises, however, the ambiguity and paradoxes of the ulama's role in the construction of 'religion' as a separate sphere of life distinct from the state. For, at the same time as separating the domain of religion from other fields of society, they have also sought to expand their role and influence in society. One of the ways they have set to this task is by seeking to play a more central role in defining the 'Islamic state' and securing their place in such a political entity.

In order to resolve this tension Zaman situates his arguments concerning the continuing influence of the ulama in Pakistan in a broader comparative perspective. It is becoming increasingly apparent that the form taken by the so-called 'Islamic revival' across the Muslim world is diverse, and that this diversity is in large part a product of the ways in which contrasting states in the Muslim world have sought to harness Islam and the ulama for their own political ends. In this book 
Zaman makes original and fruitful comparisons between Pakistan and Egypt of the type we rarely see in more narrowly focused writing on Pakistan. He argues that whilst the ulama in Pakistan have largely been successful in preventing the state from penetrating into the country's institutions of religious learning (the madrassas), in Egypt the progressive incorporation of the religious university of Al Azhar into the Egyptian state has resulted in a greater weakening of the strength and independence of the ulama. Zaman argues that it is the lack of a central seat of Islamic learning in Pakistan that has meant that the Pakistan state's attempts to regulate the activities of the ulama in the country have been less successful than those of successive modernising Egyptian regimes. In the context of the intensity of current debate in Pakistan and the US concerning the effectiveness of President Musharaf's attempts to transform the nature of Pakistan's complex network of madrassas, Zaman's discussion of this issue is both convincing and informative.

One of the greatest problems facing Pakistan over the past twenty years has been the escalation of Sunni-Shi'a violence: a combination of target killings, riots and warfare-like conflict involving Shi'a and Sunni Muslims have brought chaos to many regions of the country. In Karachi during May 2004 alone over fifty people were killed in violence between the city's Sunni and Shi'a Muslims. So in Chapter 5 Zaman provides an important analytical contribution to our understanding of sectarian conflict in Pakistan. Zaman questions approaches to the analysis of Shi'a-Sunni violence in Pakistan which argue that such conflict reflects above all else the country's political history. Nasr has recently argued that it is those factions of the ulama-centred parties that opposed the creation of Pakistan, who have been most important in the escalation of sectarian conflict over the past two decades (Nasr 2000). Such factions of the ulama have vilified Shi'a Muslims in the country as a threat to what they say is a Sunni dominated and inspired Pakistan. Embarking on such a course of action, Nasr suggests, has created for these movements a secure wedge in Pakistan's political system because they have been able to represent themselves as the sole defenders of a homogeneous and pure Sunni Pakistan. They have, thus, sought to make themselves the rightful protectors of Sunnism and Pakistan-two projects that now neatly fall into one.

Zaman has serious reservations about this argument, and whilst not dismissing it he suggests that such an approach's central weakness is that it fails to encompass the broader aims and goals of sectarianoriented and ulama-based religious parties in Pakistan. By focusing 
on a region of Pakistan that lies at the very heart of Shi'a-Sunni conflict in the contemporary Muslim world, the Jhang district of the Punjab, Zaman argues that the ulama have sought to generate antiShi'a sentiment there in order to accomplish two goals. First, following other scholars of Islamism in Pakistan, especially Nasr, Zaman argues that by 'radicalising' Muslim identities along sectarian lines some of the Sunni ulama have sought to weaken the political status and fortunes of wealthy Shi'a landlords, and, thus, create a niche for an expanding Sunni merchant middle class. Yet Zaman also argues that the sectarian profile of this deeply sensitive region is more complex than this argument suggests, and whilst many of Jhang's merchant middle class are Sunnis, there are also Shi'as amongst them. ${ }^{13}$ So, secondly, and perhaps more creatively, Zaman suggests that by seeking to radicalise Sunni identities in this and perhaps other regions of Pakistan, such anti-Shi'a Sunni ulama have also sought to further the influence that reform-minded schools of Islamic thought have in the country, most especially the Deoband 'school' established in India in 1867. Arguing that the teachings of the Deoband school have had, until recently, only a thin support base in rural regions of Pakistan, Zaman proposes that more than simply existing as a strategic political tool, sectarianism in Pakistan has also played a major role in the penetration of revivalist and reform-oriented Islamic teachings and styles of religiosity into rural areas of the country (p. 135).

An important dimension of Zaman's discussion of Shi'a-Sunni sectarianism is the distinction he makes between the 'high ranking' ulama and the 'peripheral' ulama, between those 'who have devoted themselves primarily to academic pursuits' and others who 'wage sectarian battles on the street'. This distinction is not, of course, new either to the study of Islam or Pakistan, but one of the strengths of Zaman's use of these terms is that he actively seeks to show what he sees as the high levels of interconnectivity between these classes of ulama. "The leading religious scholars do not say that the Shi'is should be killed, only that they are infidels in light of their vilification of certain early Islamic figures as well as some of their other beliefs. But enough justification is thereby provided to the peripheral ulama and their operatives-who are often little more than mercenary

${ }^{13}$ Abou Zahab 2002 seeks to explain sectarian conflict in the southern Punjab in relation to economic deprivation in the wake of the Green Revolution in the 1970s, the status and class changes this has engendered, and the growing numbers of Deobandi madrassas in the region. 
terrorists on both sides-wage an ongoing war against their sectarian opponents' (P. 133). As social scientists are now placing greater emphasis on understanding the nature of the complex networks that stretch behind the movements and organisations of Islamic revival, and Muslim identity more generally, Zaman's detailed case studies provide fascinating comparative material for scholars of other Muslimmajority states and Muslim communities elsewhere.

Zaman's contribution to our understanding of what he labels as the 'radicalisation' of Sunni identity in Pakistan, and the active role that he suggests the ulama have in this process is important, and it is likely to be a major contribution to the field of Islamic and Pakistan studies for many years to come. Yet it also raises broader questions and points to significant gaps in our understanding of the nature of Muslim thought, politics, and identity, as well as the role of the ulama in the contemporary Muslim world, and it is to these issues to which I now turn.

First, Zaman does suggest a certain degree of exchange between Sunni and Shi'a symbolism and religious language-even Sunni organisations such as the deeply anti-Shi'a Sipah-e Sahaba-e Pakistan, he suggests, place a devotional emphasis on the companions of the Prophet that is similar to the passion with which Shi'a Muslims revere their Imams. His study, however, focuses above all else on the nature of religious discourse produced by reform-minded, shari'a-centred and revivalist ulama. He argues, indeed, that the madrassa has replaced the Sufi shrine as the focal point of Muslim networks in Pakistan. What is lacking here is a consideration of the complex and multidimensional ways in which Pakistan's ulama have used, incorporated and in the process transformed the doctrines, symbols, and practices of Sufi-influenced Islamic texts and teachings in their revivalist discourses. In my experience of life in the Chitral region of northern Pakistan, even Deobandi educated ulama are often known as expert amulet makers, whilst members of the reform-minded Jama'at-e Islami party enjoy earning reputations as writers and performers of styles of love poetry and music deeply infused with the language of classic Persian Sufi texts. Sufi thought and practice continues to be a powerful source of faith and values in South Asian Islam, and there remains great diversity in styles of Muslim religiosity and identity available to believers in contemporary Pakistan. A more complete understanding of the role played by faith and religious passion in the construction of 'radicalised' Muslim identities and the religiopolitical activism of the ulama must seek to address the complex and 
challenging issue concerning the extent to which the transmission and synthesis of religious ideas and values continues to take place even in the context of hardened sectarian boundaries and violent conflict. Such an approach would allow for an even deeper understanding of the 'mercenary terrorists' responsible for so much blood shed in contemporary Pakistan.

Second, whilst Zaman clearly demonstrates the continuing importance of the ulama in the Muslim world, and provides interesting explanations for the great differences seen in the nature of the ulama's status and role in the diverse Muslim-majority settings, the ways in which Muslims living in both rural and urban settings in Pakistan respond to and receive the ulama's sermons, calls to commitment, legal injunctions and Islamising messages remain largely unexplored. Nowhere more important is it that we approach this challenging issue than in the context of Shi'a-Sunni as well as other forms of sectarian conflict in present day Pakistan. For whilst moments of violence between Sunni and Shi'a Muslims in Pakistan are now a regular feature of the country's social landscape, there are many regions of the country where Sunnis and Shi'as continue to live peacefully together, and it is in no sense possible to argue that the violent nature of Sunni-Shi'a relations is a 'routinised' and inevitable feature of life in the country. If certain sections of the ulama have sought to radicalise Sunni and Shi'a identities across Pakistan, then how successful have they been in their efforts, and how far do Muslims in the country see these men as authentic founts of pure Islam? Or, on the other hand, to what degree do 'ordinary Muslims' attempt to contest the calls to commitment of Islam's men of learning and authority, and how far are the responses of Muslims to the Islamising messages of the certain sections of the ulama about either deference or resistance in a simple and one-dimensional sense?

Nevertheless, The Ulama in Contemporary Islam will undoubtedly provoke greater interest in the role played by the ulama in politicoreligious activism in the Muslim world, and spawn lively debate concerning the form taken by the Islamic tradition in contemporary Pakistan.

\section{Migrants and Militants}

The second book under discussion here presents a very different perspective as to who are the key movers in Pakistan's present day political culture. Oskar Verkaaik's Migrants and Militants: Fun and Urban 
Violence in Pakistan, is a sensitive and much awaited subtle historical and ethnographic study of the Muhajir Qawami Movement (MQM). The MQM is an 'ethnic-based' party that has played a central role in Pakistan's politics over the past twenty years, especially in the southern cities of Karachi and Hyderabad. It is also often associated with the killings and violence that destabilised the city of Karachi over the course of this most volatile period in the city's history. The MQM's leader, Altaf Hussein, now based in a north London suburb, is the source of great debate amongst Pakistanis from an array of social backgrounds: referred to by many non-Muhajirs as a 'terrorist' protected by a hypocritical British government, and revered by many Muhajirs as a brave protector of the rights of Urdu-speaking Muslim migrants in Pakistan, the leader of the MQM is never far from controversy in the country today, yet his role in the emergence and political success of the MQM has rarely been the focus of sustained scholarly comment.

Verkaaik's work addresses this significant gap in the literature on the development of Pakistan's political culture since the 1970s. The work is especially commendable because it is based on first-hand fieldwork in one of the country's most dangerous regions, and during especially sensitive moments in Pakistan's recent history. As with Zaman's work, this book focuses on a section of Pakistan society that has largely been ignored in many accounts of the country's political history: the urban unemployed and underemployed youth. Indeed, in more general treatments of politics in the Muslim world, and in some detailed articles on 'Islamism' in Pakistan (Nasr 2002), such folk are often simply assumed to be unthinking and disoriented cannon fodder for Islamist political parties. Yet the picture Verkaaik presents is both more theoretically complex and ethnographically compelling than this older teleological and one-dimensional argument: he argues that the urban youth of the Pakistan's southern city of Hyderabad have played a central role in the region's and indeed the country's recent political fortunes. Neither resisting or unthinkingly following either the country's powerful religious or more 'secular' parties, they have, rather, constructed a symbolic and meaningful place for themselves in what is often stereotyped as being Pakistan's elite-governed political system. Furthermore, they have done so not simply by imitating or replicating the structures and ideas of other political parties in the country in line with their own concerns, but rather through creative forms of activity channelled through the deployment of discourses and experiences of 'fun'. This 'fun', however, also has a darker side: the 
division between fun and violence is a slippery one for Verkaaik, and it is only in the ecstatic play of the MQM's support base that the violent tactics of the MQM can be fully understood.

This argument is important and, indeed, resonates with my work in a very different setting in contemporary Pakistan: Khowar-speaking villagers living in the mountainous villages of Chitral in the north of the country. What I found in Chitral was that young and comparatively well-educated village Muslims did not automatically turn towards Islamist and piety-inclined movements as so many accounts of the Muslim world currently suggest. ${ }^{14}$ Many if not all of them were, rather, critical of both the teachings and the practices of Muslims they themselves referred to as 'hardened' and 'extremist'. The young village men with whom I lived did not simply reject 'Islamism': many of Chitral's youth (juanan) did join preaching tours with the worldwide movement of Islamic reform and purification, the Tabligh-e Jama'at. Yet they were also active participators in the various types of musical programmes that are much loved by many Chitral people but the focus of sustained opposition from the region's Islamizing 'bearded ones', and creative producers of poetry and song. Indeed, the lyrics of their music often sought to engage in intellectually creative and critical ways with both what they conceptualised to be the hypocritical dimensions of the ways in which Islam was practiced in the region, and Chitral's status as a neglected and marginal region of a Pukhtun-dominated Frontier province and a Punjab-domainted Pakistan. ${ }^{15}$

Such findings have important implications not just for our understanding of the comparative strength of 'Islamism' in present-day Pakistan, but also for the ways in which social scientists conceptualise Pakistan's broader political culture. Unlike some other commentators of Pakistan who continue to assume that the 'basic structure' of Pakistan's political system has remained unchanged as a result of political power remaining lodged in the hands of feudal, business and military elites, Verkaaik claims that the MQM needs to be understood as a political movement that has emerged in the context of important political changes in Pakistan. As with the Hindutva parties and organisations in India, Verkaaik analyses the emergence of the MQM, and their street culture of politics in the 1980 os and 1990s in Pakistan is a form of democratic movement. In so doing, Verkaaik makes a significant step in the anthropology of Pakistan: whilst several notable

${ }^{14}$ See Marsden 2005.

15 See Marsden forthcoming. 
historical and political analyses of the country have sought to challenge the notion that Pakistan is a distinct, indeed unique, form of political entity to its 'democratic' Indian neighbour (Jalal 1995), there have been few detailed studies of Pakistan's political culture that have sought to explore how, if at all, such an argument is relevant to the everyday forms of politics of ordinary Pakistanis. Moreover, by showing how the MQM is in no simple sense a primordial ethnic party, but, rather, the manifestation of a particular form of political action in Pakistan, and, as such, reflects transformations in Pakistan state and society, Verkaaik is also able to explore the changes that the political culture of the MQM has undergone since its creation. Rather than one-dimensional depicting the party as a movement of violence and terrorism, he shows how whilst initially the movement was one of youth mobilisation, its violent and anti-state activities and dimensions grew in importance through the 8 os and gos as it became increasingly pressurised by hostile Pakistani political regime, and, in more recent times, the MQM is now increasingly turning away from violence and exclusivist ethnic politics and seeking to build bridges with those it was once hostile to, especially Sindhi dominated political parties and movements.

Verkaaik also connects his discussion of the rise of the MMA in Karachi to the place of status and division amongst Muhajirs in Pakistan. This is a critical dimension of Pakistan society. Yet its political and symbolic significance in Pakistan's political culture has too often been sidelined by older and somewhat repetitive debates concerning the extent to which it is possible to conceptualise forms of social hierarchy in Muslim societies as manifestations of Hindulike 'caste' formations (Lindholm 1996). The scholarly exploration of this important issue has not been helped by hostility in 'Islamic' Pakistan to the very notion that caste-like forms of social distinction remain vibrant in a 'modern' Muslim society. As a result, whilst often polemical debates have raged in the study of contemporary India over the extent to which the origins of caste lie in religious values, Indian history, or colonial rule (e.g. Dirks 2001), and the degree to which caste identities are flexible in the face of modernity and social change (e.g. S. Bayly 1998), the importance of these issues in the recent political history of Pakistan have been largely overlooked. This represents a significant lacuna in our understanding of the country, not least in relation to the emergence of mass support for 'Islamic' political parties in the country, and the victory of the MMA in constituencies where powerful and high status formerly princely families have maintained 
a hold on power for much if not all of the past century (for instance, Swat, Dir, and Chitral). Yet hitherto most analyses of growing support for Pakistan's Islamist parties are based on narrow understandings of class conflict and political strategy. Most especially analyses claim that there is growing middle class support for the Islamising policies of 'religious parties', such as the Jama'at-e Islami, and that this has also resulted in subsequent attempts made by supposedly more established parties, especially the Muslim league, to wrest this support from the Islamists by using Islamic symbols and initiating Islamising policies.

Whilst Verkaaik does not deal with this complex issue directly, what he does do is to present an equally important discussion of the importance of status distinctions in the emergence of the MQM party and its support base amongst Urdu-speaking migrants to Pakistan. In so doing, he goes a long way in challenging the notion that the MQM and other parties like it thrive on any simple form of ethnic identity and community in Pakistan, emphasising, rather, the tensions and conflicts embedded in such linguistic and neighbourhood forms of collective identity. It is widely known that the MQM's support base is almost exclusively amongst Indian Muslims who moved to Pakistan as refugees (muhajirs) with the partition of India in 1947. Yet Verkaaik's work on the large and important Muhajir community in Hyderabad is the first work that explores in detail the tensions, anxieties and divisions that underlie any simple notion held both by scholars and the Pakistani media more generally, of their being any 'pure' Muhajir community in Hyderabad or elsewhere. This key ethnographic chapter is important: the divisions and tensions between Muhajirs in Pakistan are too often overlooked in scholarly writing on the country.

In chapter 3 Verkaaik provides an evocative discussion of the tensions within the Hyderabadi Muhajir community: distinctions between Sunni and Shi'a, high status and low status, and Muhajirs hailing from the Indian cities of Ajmer and Agra reveal the conflictual nature of everyday social relations amongst Muhajirs in the city, and Verkaaik documents how what he calls 'the politics of insult and prejudice' played themselves out in the daily life of the city's Mujhajir community. This is important because it provides the historical backdrop before which the MQM emerged as a powerful force for the mobilization and empowerment—albeit uneven—of the city's youth. But it is also important because status distinction and competition must be seen as central to the nature of society and politics in Pakistan more generally, and Verkaaik, through discussions of the use of insults such as 'black' (kaliya) shows how the 'politics of insult' was masterfully 
turned on its head through parody and fun and deployed for very different purposes by 'the youth' who went on to form the bulk of the MQM movement in the eighties and nineties.

The book also a makes a significant contribution to the understanding of the interaction between Islam and ethnicity in Pakistan. Scholars of Pakistan are often rightly bewildered by the diverse and competing forms of Muslim political parties, identities and traditions in the country, and the degree of conflict and tension between these. All too often, divisions between 'high' and 'low' Islam, 'Islamist' and 'neofundamentalist' religious parties, and 'modernist' and 'traditional' forms of Muslim identity are treated by scholars of the country as separate and incommensurable wholes that are mapped onto society in Pakistan in a one-dimensional and self-defining way. Verkaaik's analysis of this remarkably multi-layered religious setting is far more convincing. He shows how the MQM promoted a Muslim identity that was 'a paradoxical reconciliation of complimentary but contradictory discourses on Muslim nationalism and ethnic solidarity, Islamic modernism and Sufism' (p. 185), and that this reconciliation of complex and seemingly incompatible sets of discourses was made possible by the creative fun which lay at the heart of the MQM's mode of political action. In arguing such, Verkaaik allows us to think in new ways about the role played by religious symbolism and authority in Pakistan's multi-layered political culture. First, and most generally, he shows how those who have argued that Pakistan's political culture is one-dimensionally saturated by Islamic symbols and discourses which have for years been given heightened capital and value by the intermittently Islamizing state are simplistic at best. Rather, Verkaaik's book asks more penetrating questions about how such symbols and discourses are reproduced, manipulated and even parodied by the country's politicians and their supporters, and one domain of political life in Pakistan where Verkaaik's arguments are especially insightfully is in relation to the nature of Sunni-Shi'a relations as conceptualised by muhajirs.

Indeed, in relation to the study of sectarian conflict in Pakistan, Verkaaik's work in some ways starts where Zaman's ended. The ethnographic focus of Verkaaik's book means that it includes material and analysis lacking in other less situated accounts of the nature of Shi'a-Sunni violence in contemporary Pakistan. Verkaaik documents in a nuanced way the interplay between discourses of sectarian and ethnic identity both in moments of violent conflict and in political 
mobilisation in Pakistan more generally. ${ }^{16}$ His book is important at two major levels. First, he shows how complex and intricate the relationship between supposedly sectarian and ethnic forms of conflict both in Pakistan's recent and earlier history are. In his discussion of a Shi'a-Sunni riot in Hyderabad in 1955, for instance, we learn how clear-cut accusations by Hyderabad people of sectarian violence seemingly faultlessly merged into a broader discourse of accusation and counter accusation by both Muhajirs and Sindhis of the other's essential Shi'aness. Second, he documents in detail how what are usually said to be deeply Shi'a symbols, values and forms of emotion, are, in southern urban Pakistan at least, deployed for political mobilisation and motivation by parties that in no simple sense are 'Shi'a': martyrdom, the evoking of the Karbala narrative and ethic, and the use of Shi'a-like bodily dispositions and clothing form one critical way in which the MQM garnered support for its notion that the Muhajirs are a maligned ethnic group in what they conceptualise as a Punjab-dominated Pakistan. What we are left with, then, is a suspicion that much of what is often called sectarian conflict in Pakistan is less about radicalised Shi'a and Sunni identities per se, or, indeed, the inevitable result of any simple configuration of material factors, than forms of conflict in which narratives of accusation and counter accusation are central.

In summary, Verkaaik's book is the first in-depth study of the MQM movement, and provides material about the MQM and the lives and dispositions of its supporters that have hitherto not been the focus of scholarly research. In so doing, Verkaaik goes a long way in transforming our understanding of the movement as simply a 'violent' 'ethnic' party to a more grounded approach that explores in detail the economic, cultural, political and religious tensions that lay behind the emergence of the MQM and the killings with which it became associated in the eighties and nineties. The book is important for the contemporary understanding of Pakistan more broadly because it is the first ethnographically informed historical study of a political party in a country where, despite years of military rule, affiliation to and membership of political parties remains a salient feature of both personal and collective identity. It does, thus, significantly add to our understanding of the impact of new forms of political mobilisation

\footnotetext{
${ }^{16}$ For an anthropological analysis of Sunni-Shi'a relations in another urban setting in Pakistan, Gilgit in the Northern Areas, see Sokefeld 1999.
} 
on public life in a so-called 'authoritarian state'. For anthropologists interested in the study of urban politics, the book's central argument is a significant contribution to the anthropological study of political violence and the understanding of militant movements.

\section{Pilgrims of Love}

Pnina Werbner's Pilgrims of Love: The Anthropology of a Global Sufi Cult advances a very different understanding to both Zaman and Verkaaik of the role played by religion in the everyday lives of Pakistani Muslims, living both inside the country and elsewhere, especially in the United Kingdom. Werbner's work questions especially Zaman's claim that the reformist madrassah has replaced the Sufi lodge as central to the nature of Islamic networks in Pakistan. Werbner, rather, provides a detailed and first-hand account of a Sufi lodge that appears to be a thriving and dynamic feature of Pakistan society. Moreover, the Sufi centre that Werbner visited in the early 1990 s is not located in a region of Pakistan where the Sufi tradition is recognised as being especially influential: the lodge of Zinda Pir, rather, is located in the Kohat region of the country's North West Frontier Province. Yet the followers of the lodge come from many regions of Pakistan, and the lodge itself has branches in an array of exceptionally diverse Pakistani settings. Most strikingly these include locations such as what is usually assumed to be the Deobandi dominated Dir district of the Frontier. In relation to the study of Pakistan, however, what is especially fascinating is that this brotherhood not only has followers from different regions of Pakistan, but also frequently brings them together in moments of shared religious ritual, and that this occurs despite the differences of the settings from which the followers of the saint hail.

Indeed, the overwhelmingly Pakistan-centred orientation of the 'cult', both within Pakistan and beyond appears so strong in Werbner's account, that it makes one wonder whether this is, from the perspectives of the followers themselves, the global religious movements that the title of Werbner's book claims. Of course, 'reformist' movements such as the Tabligh-e Jama'at and more politically oriented Islamist parties have been involved in the creation of global networks over the past fifty years. ${ }^{17}$ Yet what Werbner documents is especially interesting because there have been few interregional studies of

${ }^{17}$ See Roy and Abou Zahab 2004. 
Sufi cults in Pakistan: Islam specialists usually argue that Islamic reformism is the main force behind the homogenisation of the thinking and practices of Pakistan's Muslims, not the activities of the Sufi brotherhood. Moreover, the murids of the 'cult' of Zinda Pir are not simply village Muslims untouched by the teachings of reformist Islam, they are, rather, from all regions of Pakistan, many of them migrants to Britain, and some of the key leaders within the movement affiliated themselves to it during their careers both as officers and soldiers in the Pakistan Army. Thus, whilst Pilgrims of Love contains a rich body of material on Sufism and Islam in Pakistan and its diasporic communities, it is less instructive on the form taken by present day constructions of Pakistani national identity and the vexed question concerning how these relate to variations in regional and religious identity in the country.

There are, however, some problems with the approach taken by Werbner in regard to this most important and complex of issues. Most obviously, perhaps, there is little recognition of the broader religious and social context of Zinda Pir's lodge. Werbner's research in Pakistan was undertaken in a complex cultural and political region where both Pashto and Punjabi are important local spoken languages. Unfortunately, the ways in which affiliation to this Sufi lodge transcends cultural and linguistic divides in Pakistan do not form any part of the main argument of the book, despite the fact that ethniclinguistic conflict has occupied such a central part of life in Pakistan over the past twenty years. This is perhaps an issue of even more considerable importance when one takes into consideration Werbner's focus on Pakistan's 'diaspora communities'. Locality politics are even a central feature of political life in Pakistani and diasporic communities, and, as anybody who has surveyed web chat rooms frequented by Pakistanis in Britain will know, the tensions and conflicts between British Pakistanis of 'Pukhtun' and 'Punjabi' descent are as, if not more, powerful in the streets of Birmingham as they are in the bazaars of Peshawar. How the followers of Zinda Pir negotiated and conceptualised such issues would have added a further important theme to this work.

Moreover, whilst Werbner's attempt to complicate our understanding of the interaction between Sufi and reformist Islam is successful, there is a greater need to recognise that Kohat is a region of Pakistan where madrassas teaching relatively hard line interpretations of Islam are now powerful and influential. Indeed, one would presume that returnee madrassa students do form a part of the religious horizons of 
the people with whom Werbner lived, both in Pakistan and in Britain. Moreover, especially in settings such as Dir where both the Afghan Taliban and the Pakistan MMA have been and continue to be powerful and influential, the degree to which the followers of Sufi cults have to contend with more reform-oriented fellow Frontier people would, one would imagine, be central to understanding the dynamics of the cult of Zinda Pir. Yet Werbner is of the opinion that the power of Pakistan's 'Islamist' parties is over exaggerated. Indeed, their only real mention is in a footnote, when she notes that the 'religious parties' in Pakistan are 'not strong' and that their successes in the 2002 elections were above all else to do with 'unusual' circumstances, including America's attacks on Afghanistan and the military government's attempt to weaken the country's more established political leadership. Such a cursory dismissal is over simplistic. As I have suggested above, such arguments conceal the socio-economic factors that have played a powerful role in making the MMA political force in the Frontier, at the same time as obscuring the ideological dimensions of the MMA which for some if not all Frontier Muslims make the movement a politically, if not necessarily religiously, persuasive one. ${ }^{18}$ In short, both the relationship between 'Islamic', national and region identity, and the interaction between religious politics and social transformation in Pakistan is more complex than Werbner's analysis suggests.

In the context of this article, however, what I am interested in most is the significance that Werbner's detailed ethnographic study has, or rather could have, for our understanding of contemporary Pakistan. In this regard the book, somewhat inevitably given its lofty philosophical and anthropological goals, is less informative, and, on some occasions, one wonders how far Werbner is prepared to recognise the influence that Pakistan as a cultural, political and religious entity has on her Sufi informants. Much of the material in the book could have been used to argue decisive points about the nature of contemporary Pakistan, but Werbner prefers to focus on the anthropology of religion and a critique of 'post-modern' theory. Thus, I now reflect on the implications of some of her ethnography for the understanding of contemporary Pakistan.

This is especially the case regarding the fascinating issue concerning the close relationships between the 'cult' of Zinda Pir and the Pakistan Army. The central lodge of the Zinda Pir lodge is located close to the important Pakistan Army cantonment town of Kohat, and Werbner

\footnotetext{
${ }^{18}$ For an insightful critique of dominant understandings and explanations of 'political Islam' in the social sciences, see Hirschkind 1997.
} 
discusses how many men in the army came to know of and eventually affiliate themselves with the 'cult' during their time in the Pakistan Army, as both soldiers and officers. Indeed, many of these figures, including the saintly head of the movement in Britain, went on to play an important role in the 'cults' development. This is all striking: recent accounts of the Pakistan Army have largely claimed, especially since General Zia's time as the country's military President, that the Army has increasingly become dominated by a type of middle class, Islamist inclined, often rural, young officer, who is hostile to the teachings and practices of so-called 'popular' and 'Sufi' Islam, and, instead, highly influenced by the ideologies of parties such as the Jama'at-e Islami. ${ }^{19}$ Indeed, in more recent years, some journalists have suggested that some officers in the Pakistan Army have now started to turn towards even more 'extremist' forms of Islamic faith and action which emphasise in an even clearer way the role that violent struggle and strict interpretations of the Islamic legal code should play in the living of a Muslim life in Pakistan. Of course one of the great problems with this approach is that it assumes that Pakistan's newly educated and now urban-based rural folk homogeneously turn towards the teachings of 'reformism' when their economic, class, and educational status undergoes an upward change. This is why the very different dynamic between the army and religion taking place in the context of a global Sufi brotherhood is such an interesting dimension of Werbner's book, and there appears to be the potential of arguing that recent accounts of the Pakistan Army have over homogenised the role of Islam and the type of Muslim important within it, and over simplified the forms of religious conflict important at a number of different levels within the Army's organisational structure.

\section{Conclusion}

Two major points emerge from this discussion of recent literature to emerge on the state of contemporary Pakistan. First, in relation to the understanding of Islam in Pakistan, what all the books reviewed show is that it is no longer sufficient to simply emphasise either the diverse cultural variations important in Pakistan that impact on the complex form taken by the Islamic tradition in Pakistan, or to conceptualise Pakistan as dominated and divided by competing Islamic sectarian

${ }^{19}$ For one of the first such accounts of this process of change in the Pakistan Army, see Cohen 1998. 
identities and doctrines. The Muslims whose lives are explored in these books are Muslim in ways that are neither the product of an ethnicizing state, nor the efforts of Islamizing movements. Rather, there is a greater degree of flexibility and creativity in the ways in which Pakistan people think about Islam than is usually assumed. This is not simply something that is contained within any ideo-typical realm of personal religion but, rather, impacts in profound and important ways on the different strategies the country's Muslims have deployed in order to engage themselves in movements of political mobilisation.

Second, it is now also clear that older social science conceptualizations which depict Pakistan as an authoritarian state with little or no space for democratic values or processes, have hindered the state of scholarly understandings of Pakistan, and, more generally, work on the nature of democracy in postcolonial countries more generally. In particular there is an urgent need to explore the complex relationship between the nature of the Pakistan state, the form taken by centreprovince relationships in the country, and the interaction between this and the supposed growing support for parties with a so-called 'Islamist' platform in the country. Until now Islamist movements in Pakistan have been too easily depicted either as in a symbiotic relationship with the military or in opposition to the elite classes and forces of the 'praetorian' Pakistan state. Consequently, their influence on Pakistan's political culture, and the form taken by critical political debate in the country have been both underestimated and undertheorised.

\section{Bibliography}

Abou Zahab, M. 2002. Sectarianism as a substitute identity: Sunnis and Shias in central and south Punjab. In Mumtaz, S., Racine, J. L. and Ali, I. A., Pakistan: The Contours of State and Society. Karachi: Oxford.

Banerjee, M. 2000. The Pathan Unarmed: Opposition and Memory in the North West Frontier Province. Oxford: James Currey.

Bayly, S. 2001. Caste, Society and Politics in India from the Eighteenth Century to the Modern Age. Cambridge: Cambridge University Press.

Bennet Jones, O. 2002. Pakistan: Eye of a Storm. New Haven and London: Yale University Press.

Cloughly, B. 200o. A History of the Pakistan Army: Wars and Insurrections. 2nd edition, with a New Chapter on the Kargil Issue. Oxford: Oxford University Press.

Cohen, A. 1998. The Pakistan Army. Karachi: Oxford University Press.

Dirks, N. 2001. Castes of Mind: Colonialism and the Making of Modern India. Princeton, N. J.: Princeton University Press.

Eickelman, D. and Anderson,J. (eds). 1999. New Muslim Media in the Muslim World: The Emerging Public Sphere. Bloomington: Indiana University Press.

Hansen, T. 2001. Wages of Violence: Naming and Identity in Postcolonial Bombay. Princeton, N.J.: Princeton University Press. 
1999. The Saffron Wave: Hindu Nationalism and Democracy in Modern India. Princeton, N. J.: Princeton University Press.

Harrison, S. 1981. In Afghanistan's Shadow: Baluch Nationalism and Soviet Temptations.

Washington D. G.: Carnegie Endowment for International Peace.

Hirschkind, C. 1997. What is political Islam. Middle East Report 274.

Jaffrelot, C. (ed.) 2002a. Pakistan: Nationalism without a Nation. London: Zed Books. 2002b. A History of Pakistan and its Origins. London: Anthem Press.

Jalal, A. 1995. Democracy and Authoritarianism in South Asia: A Comparative and Historical Perspective. Cambridge: Cambridge University Press.

- 1990. The State of Martial Rule: The Origins of Pakistan's Political Economy of Defence. Cambridge: Cambridge University Press.

—. 1985. The Sole Spokesman: Jinnah, the Muslim League and the Demand for Partition. Cambridge: Cambridge University Press.

Levy, B.-H. 2003. Who Killed Daniel Pearl. London: Gerald Duckworth and Co. Ltd.

Lindholm, C. 2002. Kissing cousins: anthropologists on Islam. In Donnan, H. Interpreting Islam, pp. 1 10-29. London: Sage.

Marsden, M. Forthcoming (2005). Muslim village intellectuals: the life of the mind in Northern Pakistan. Anthropology Today. 21 (1): 10-15.

- Forthcoming (b). Muslim Religious Experience in North Pakistan. Cambridge: Cambridge University Press.

Nasr, S. V. R. 2002. The Iranian revolution and changes in Islamism in Pakistan, India and Afghanistan. In Keddie, N. and Matthee, R. Iran and the Surrounding world: Interactions in Culture and Cultural Politics. Seattle and London: University of Washington Press.

- 2001. Islamic Leviathan: Islam and the Making of State Power. Oxford: Oxford University Press.

- 2000. The rise of Sunni militancy in Pakistan: the changing role of Islamism and the Ulama in society. Modern Asian Studies 34 1: 139-80.

—. 1996. Mawdudi and the Making of Islamic Revivalism. New York and Oxford: Oxford. University Press.

- 1994. The Vanguard of the Islamic Revolution: The Jama'at-I Islam of Pakistan. Berkeley: University of California Press.

Rai, M. 2004. Hindu Rulers, Muslim Subjects: Islam, Community and the History of Kashmir. London: Hurst and Co.

Roy, O. and Abou Zahab, M. 2004. Islamist Networks: The Afghan-Pakistan Connection. London: Hurst and Co.

Samad, Y. 1995. Pakistan or Punjabistan: crisis of national identity. International Journal of Punjab Studies 2 1: 23-42.

- 1995. A Nation in Turmoil: Nationalism and Ethnicity in Pakistan 1937-1958. New Delhi: Sage.

Shah, S. W. A. 1999. Ethnicity, Islam and Nationalism: Muslim Politics in the North-West Frontier Province 1937-47. Karachi: Oxford University Press.

Sokefeld, M. 1999. Debating self, identity, and culture in anthropology. Current Anthropology 40.4: 417-47.

Talbot, I. 2002. The Punjabization of Pakistan: myth or reality. In Jaffrelot, C. (ed.) Pakistan: Nationalism without a Nation. London: Zed Books.

Titus, P. (ed.). 1997. Marginality and Modernity: Ethnicity and Change in Post-colonial Balochistan. Oxford: Oxford University Press.

Titus, P. 1998. Honour the Baluch, buy the Pashtun: stereotypes, social organisation and history in West Pakistan. Modern Asian Studies 32 3: 689-716.

Zutshi, C. 2004. Languages of Belonging: Islam, Regional Identity and the Making of Kashmir. London: Hurst and Co. 